\title{
Relasi Kekerabatan Patronase Masyarakat Muna
}

\author{
Asliah Zainal \\ Fakultas Ushuluddin, Adab, dan Dakwah Institut Agama Islam Negeri Kendari, Indonesia \\ liazain03274@gmail.com \\ Muhammad Asrianto Zainal \\ Fakultas Syari'ah Institut Agama Islam Negeri Kendari \\ asrianto.zainal1@gmailcom \\ Waode Ainul Rafiah \\ Fakultas Ushuluddin, Adab, dan Dakwah Institut Agama Islam Negeri Kendari, Indonesia \\ waodeainulrafiah28@gmail.com

\section{Wa Kina} \\ Fakultas Ushuluddin, Adab, dan Dakwah Institut Agama Islam Negeri Kendari, Indonesia \\ waqina77@gmail.com
}

\begin{abstract}
This study is addressed to two things: the relationship of kinship and patronage, which take place in social aspect (education and economy) and culture (life cycle ceremony), and the relation of patronage kinship system, which implies on cohesion social community of Muna. This study showed that the relation of the Muna family was tied socially and culturally by two vertices, descent/affinity relation and patronage relation or patronage kinship system and in local term called intaidi bhasitie (we are family). The patronage kinship in Muna family works in almost every aspect of community life, both in social; educational, economic, even political; and cultural (life cycle ceremony). By using Anthropological family, this study argues that the kinship systems wrapped by patronage or boosted patronage by kinship relationships are neither firm nor sustainable. It may be safe in education, economy, and cultural aspects but may be weakened in political preference. Even though a relative still tied up in a family's node but his indifference will be called "family but not". This social relationship will threaten the bond of kinship that eventually fragile and unravel, and the social relation seems to be a pseudo kingship. This research implies that the social relations of patronage kinship will threaten kinship ties which are eventually fragile and unravel, resulting in pseudo kingship if the conditions for a patron-client as Scott's theory are not fulfilled, and eventually become a transactional relationship bond. This research is expected to provide an understanding that kinship ties or patronage relations are traditionally socio-cultural capital that is increasingly threatened by the demands of economic and political interests in modern transactional relationships.
\end{abstract}

Keywords: Muna society, patron-client, social cohesion, system of kingship.

Abstrak
Studi ini bertujuan untuk mengkaji dua hal, yaitu bagaimana hubungan kekerabatan dan relasi
patronase berlangsung dalam aspek sosial (pendidikan dan ekonomi) dan budaya (upacara daur
hidup); dan bagaimana relasi tarik menarik sistem kekerabatan patronase tersebut berimplikasi
pada kohesi sosial masyarakat Muna. Hasil studi menunjukan bahwa relasi keluarga Muna
diikat secara sosial dan kultur oleh dua simpul, yaitu relasi kerabat dan relasi patronase atau
kekerabatan patronase dan dalam istilah lokal disebut intaidi bhasitie (kita adalah keluarga).
Gejala kekerabatan patronase dalam keluarga Muna bekerja dalam hampir semua aspek
kehidupan masyarakat, baik aspek sosial (pendidikan, ekonomi, bahkan politik) dan budaya
(pelaksanaan tradisi atau upacara daur hidup). Dengan menggunakan pendekatan Antropologi
keluarga, artikel ini beragumen bahwa jalinan kekerabatan yang dibungkus oleh relasi


patronase atau sebaliknya patronase yang dikuatkan dengan relasi kekerabatan tidaklah mapan dan tidak pula bersifat langgeng. Ia bisa saja aman pada aspek-aspek sosial tertentu (pendidikan dan ekonomi) dan budaya (upacara daur hidup), tetapi bisa melemah pada aspek sosial lainnya (preferensi politik). Seorang kerabat, meskipun ia masih diikat dalam simpul kerabat akan tetapi sikap acuh tak acuh atau tiadanya kepedulian dengan kesulitan keluarga, maka ia akan disebut sebagai "keluarga tapi bukan". Penelitian ini mengimplikasikan bahwa relasi sosial kekerabatan patronase akan mengancam ikatan kekerabatan yang akhirnya rapuh dan terurai yang berakibat pada ikatan kekerabatan semu (pseudo kingship), jika persyaratan terjadinya patron-client sebagaimana teori Scott tidak terpenuhi, dan akhirnya hanya akan menjadi ikatan relasi transaksional. Penelitian ini diharapkan dapat memberikan pemahaman bahwa ikatan kekerabatan ataupun relasi patronase secara tradisional merupakan modal sosial budaya yang makin terancam dengan tuntutan kepentingan ekonomi dan politik pada hubungan transaksional modern.

\section{Kata Kunci: sistim kekerabatan, patron-klien, masyarakat Muna, kohesi sosial}

\section{A. Pendahuluan}

Sistem patronase menjadi hal yang jamak di banyak negara, terutama negara-negara dengan system paternalistic dan patriarchy yang kental. Relasi patronase bekerja dalam beberapa aspek, seperti dalam aspek pendidikan ${ }^{1}$ dan yang paling mencolok dalam aspek politik $^{2}$, sebagaimana terjadi di Amerika ${ }^{3}$, negara $\mathrm{Arab}^{4}$, India ${ }^{5}$ dan di Afrika ${ }^{6}$.

Di Indonesia, meskipun menjadi fenomena yang umum terjadi, studi tentang relasi patronase dalam sistem kekerabatan belum begitu banyak dilakukan kecuali pada masa kontemporer. Gejala patronase dalam banyak masyarakat dapat bekerja dalam berbagai aspek,

\footnotetext{
${ }^{1}$ Morgan, S. L., Mohammed, I. Z., \& Abdullahi, S. (2010). Patron-Client Relationships and Low Education among Youth in Kano, Nigeria. African Studies Review, 53(1), $79-103$. https://doi.org/10.1353/arw.0.0236; Lihat juga Eilenberg, M. (2012). The confession of a timber baron: patterns of patronage on the Indonesian-Malaysian border. Identities, 19(2), 149-167. https://doi.org/10.1080/1070289x.2012.672841; Mccauley, J. F. (2013). Africa's new big man rule? Pentecostalism and patronage in ghana. African Affairs, 112(446), 1-21. https://doi.org/10.1093/afraf/ads072; Akhtar, A. S. (2011). Patronage and class in Urban Pakistan: Modes of labor control in the contractor economy. Critical Asian Studies, 43(2), 159-184; Ferrol-Schulte, D., Ferse, S. C. A., \& Glaser, M. (2014). Patron-client relationships, livelihoods and natural resource management in tropical coastal communities. Ocean and Coastal Management, 100, 63-73. https://doi.org/10.1016/j.ocecoaman.2014.07.016; Adams, C., \& Neef, A. (2019). Patrons of disaster: The role of political patronage in flood response in the Solomon Islands. World Development Perspectives, 15(August). https://doi.org/10.1016/j.wdp.2019.100128.

${ }^{2}$ Leonard, D. K., Brass, J. N., Nelson, M., Ear, S., Fahey, D., Fairfield, T., Gning, M. J., Halderman, M., McSherry, B., Moehler, D. C., Prichard, W., Turner, R., Vu, T., \& Dijkman, J. (2010). Does patronage still drive politics for the rural poor in the developing world? A comparative perspective from the livestock sector. Development and Change, 41(3), 475-494. https://doi.org/10.1111/j.1467-7660.2010.01647.x

${ }^{3}$ Polo Y La Borda, A. (2019). Don Mauro's Letters: The Marquis of Villagarcía and the Imperial Networks of Patronage in Spain. Americas, 76(4), 555-583. https://doi.org/10.1017/tam.2019.70

${ }^{4}$ Corstange, D. (2018). Kinship, partisanship, and patronage in Arab elections. Electoral Studies, 52, 5872. https://doi.org/10.1016/j.electstud.2018.01.006; Flammini, R. (2010). Elite emulation and patronage relationships in the Middle Bronze: The Egyptianized dynasty of byblos. Tel Aviv, 37(2), 154-168. https://doi.org/10.1179/033443510x12760074471026

${ }^{5}$ Javid, H. (2011). Class, power, and patronage: Landowners and politics in Punjab. History and Anthropology, 22(3), 337-369. https://doi.org/10.1080/02757206.2011.595006; Anwar, M. F. (2018). Patronage and Political Affiliation : Case Study of Village Jhok Bodo, District Dera Ghazi Khan, West Punjab. 98-116.

${ }^{6}$ Beresford, A. (2015). Power, patronage, and gatekeeper politics in South Africa. African Affairs, 114(455), 226-248. https://doi.org/10.1093/afraf/adu083; Vokes, R. (2016). Primaries, patronage, and political perso in South-western Uganda. Journal of Eastern African Studies, 10(4), 660-676. https://doi.org/10.1080/17531055.2016.1278324.
} 
misalnya dalam aspek sosial, ekonomi, budaya, dan politik. Penelitian Varkkey ${ }^{7}$ menjelaskan bagaimana patronase digunakan oleh investor Malaysia dan Singapura yang terjadi di negara mereka ke dalam praktik patronase di Indonesia dalam pembakaran hutan yang menguntungkan negara tersebut dan juga para pebisnis lahan gambut di Indonesia, meskipun merugikan bagi masyarakat mereka sendiri. Aida et al, melakukan penelitian hubungan patronase antara nelayan dan pemilik modal di Siwa terjadi dalam aspek ekonomi dan non ekonomi. Aspek ekonomi terjadi pemilik modal memberi bantuan biaya operasional penangkapan bagi nelayan dan sebaliknya nelayan memasok ikan hasil tangkapan kepada pemilik modal. Sedangkan nonekonomi dilakukan pemilik modal dengan memberikan pinjaman kepada nelayan yang ingin bekerja tanpa dana, pemberian akses kerja ${ }^{8}$. Supartiningsih dalam penelitianya menemukan bahwa Ajjoareng dan joa' dalam masyarakat Bugis merupakan proses jalinan hubungan dengan sukarela dan karenanya dapat dihentikan dan diakhiri kapan saja ${ }^{9}$. Masih dalam lokus Sulawesi Selatan, Purwaningsih menjelaskan bahwa sistem kekerabatan dapat saja bekerja dalam ranah politik, dimana Pilkada langsung dan sistem pemilu proporsional dengan suara terbanyak memberikan kesempatan yang lebih besar kepada keluarga politik untuk memperoleh atau memperbesar kekuasaannya ${ }^{10}$. Dengan lokus berbeda, yaitu di pesantren, Setiawan melakukan penelitian tentang gejala patronase di PP Daarul Fikri Mulyoagung Dau Malang dan menemukan dua tipe hubungan petron klien antara kiai dan santri, yaitu pola hubungan guru-murid dengan pola formal dan pola hubungan emosional antara bapak dan anak yang dipengaruhi oleh faktor intern dan ekstern. Faktor intern berasal dari diri kiai yang memandang santri sebagai amanat yang harus dididiknya sebagaimana anaknya sendiri. Faktor ekstern berasal dari tradisi orang tua santri yang menyerahkan anaknya kepada kiai secara langsung dan juga didukung oleh anggapan santri terhadap kiai sebagai orang tua sendiri ${ }^{11}$. Dalam masyarakat Sunda, sebagaimana temuan Hidayat bahwa sistem kekerabatannya disebut dengan pancakaki, dimana sesepuh sebagai pemimpin keluarga yang dituakan bertindak sebagai patron yang berfungsi melindungi anggota keluarganya dan sekaligus mewariskan nilai-nilai kepada para klien (para santri). Dalam ikatan keluarga yang kuat, seorang individu merasa mendapat perlindungan dan merasa $\operatorname{aman}^{12}$. Sistem kekerabatan dalam masyarakat Arab sebagaimana temuan Shahab dapat saja terburai. Ia menemukan bahwa laki-laki senior dalam keluarga Arab yang tadinya menjadi pemimpin keluarga sekaligus menjadi tokoh masyarakat dalam masyarakat urban menjadi berubah; fungsinya menjadi hilang, frekuensi interaksi keluarga menjadi amat rendah, lemahnya kesadaran dan kebanggaan kelompok, absennya anggota keluarga dalam perayaan-perayaan keluarga, dan waktu pertemuan keluarga menjadi amat singkat ${ }^{13}$. Smith menjelaskan bagaimana masyarakat migran dari etnis Igbo di Nigeria menginginkan untuk dimakamkan di rumah di desa leluhur mereka dalam bentuk upacara

\footnotetext{
${ }^{7}$ Varkkey, H. (2012). Patronage politics as a driver of economic regionalisation: The Indonesian oil palm sector and transboundary haze. Asia Pacific Viewpoint, 53(3), 314-329. https://doi.org/10.1111/j.14678373.2012.01493.

${ }^{8}$ Aida, K. N., Agustang, A., Arlin, A., \& Agustang, A. D. M. (2020). The patron-client relationship patterns in Siwa Lima fishermen community, Aru Islands district Maluku, Indonesia. International Journal of Scientific and Technology Research, 9(2), 74-77.

${ }^{9}$ Supartiningsih, 2010. "Konsep Ajjoareng-Joa' dalam Tatanan Sosial Masyarakat Bugis (Perspektif Filsafat Sosial)", Jurnal Filsafat. 20 (3), Desember: 217-238.

${ }^{10}$ Titin Purwaningsih, 2015. "Politik Kekerabatan dan Kualitas Kandidat di Sulawesi Selatan". Jurnal Politik. 1 (1), Agustus: 97-123.

${ }^{11}$ Eko Setiawan, 2012. "Eksistensi Budaya Patron Klien dalam Pesantren: Studi Hubungan antara Kiai dan Santri”. Jurnal Ulul Albab, Volume 13, Nomor 2. DOI: http://dx.doi.org/10.18860/ua.v0i0.2372: 137-152.

${ }^{12}$ Ade Hidayat, 2017. "Pola Pewarisan Nilai Yang Berimplikasi Bimbingan Pada Pancakaki Bani Nurya", JOMSIGN: Journal of Multicultural Studies in Guidance and Counseling. 1 (1), Maret: 99-122, hlm. 102.

${ }^{13}$ Yasmin Zaki Shahab, 2005. "Sistim Kekerabatan sebagai Katalisator Peran Ulama Keturunan Arab di Jakarta”. Jurnal Antropologi Indonesia. 29 (2): 123-141.
} 
pemakaman yang mahal dan kompleks. Hal ini bermula dari ketidaksetaraan hubungan patronklien diantara kerabat antara masyarakat desa dengan kerabat migran mereka. ${ }^{14}$

Penelitian-penelitian di atas dikategorikan dalam dua hal, yaitu penelitian yang melihat hubungan kekerabatan dalam keluarga, sebagaimana yang dilakukan oleh Hidayat dan Shahab. Kedua adalah penelitian-penelitian yang berfokus pada hubungan patronase dalam berbagai masyarakat dan dalam banyak aspek (sosial, ekonomi, politik, dan budaya, seperti yang dilakukan Supartiningsih, Ahimsa-Putra, dan Setiawan (aspek sosial); dalam aspek ekonomi sebagaimana studi yang dilakukan Varkkey, Aida, Mirajiani, Suprihatin, dan Hefni; patronase dalam aspek budaya sebagaimana dijelaskan oleh Smith.

Pada masyarakat Muna, secara tradisional gejala kekerabatan masih sangat kental pada satu sisi, terutama sangat terlihat pada perayaan-perayaan upacara daur hidup. Namun pada sisi yang lain, relasi patronase juga bekerja dalam berbagai aspek social, ekonomi bahkan politik. Penelitian ini berbeda dengan penelitian-penelitian sebelumnya, dimana akan mengkaji relasi kekerabatan yang tidak lagi murni bekerja diantara kerabat, tetapi sudah berbalut relsi patronase yang tidak hanya melibatkan keluarga secara hubungan darah dan perkawinan, namun di luar kerabat biologis. Studi-studi di atas, baik yang difokuskan pada sistem kekerabatan maupun relasi patronase memiliki perbedaan dengan studi ini, dimana hubungan patronase dalam masyarakat Muna meskipun di luar keluarga sedarah dan perkawinan dianggap sebagai kerabat. Seorang patron juga tidak melulu berasal dari orang yang sangat kaya atau bangsawan. Sehingga, kekerabatan di Muna diikat bukan saja oleh hubungan darah dan perkawinan, tetapi juga patronase yang terjalin bukan diantara kerabat sekalipun.

Patronase atau hubungan antara patron-klien adalah hubungan yang terjalin antara satu orang dengan orang lainnya atas dasar saling menguntungkan dan bersifat tidak tetap. Menurut Scott, gejala patronase memiliki ciri-ciri sebagai berikut: pertama, adanya ketidakseimbangan (inequality) dalam pertukaran. Patron berada dalam posisi pemberi barang atau jasa yang sangat diperlukan bagi klien dan keluarganya. Para klien sebaliknya merasa wajib membalas pemberian tersebut. Selama patron masih mampu memenuhi kebutuhan klien yang paling pokok, maka ia tetap menjadi patron, jika tidak maka seorang klien akan melepaskan diri dari hubungan tersebut tanpa adanya sangsi. Kedua adalah bersifat tatap muka. Hubungan patron klien adalah hubungan pribadi yang didasari rasa saling percaya, tanpa perjanjian tertulis. Ketiga adalah sifatnya yang luwes dan tidak hanya pada kebutuhan tertentu, tetapi meluas pada kebutuhan-kebutuhan lain ${ }^{15}$. Konsep ini berbeda dengan konsep patronase yang dikemukakan Popkin yang melihat relasi patrin-klien dengan pendekatan ekonomi politik. Popkin melihat bahwa gejala patronase adalah sistem eksploitasi patron terhadap para petani yang membuat para petani sebagai klien merasa tertekan ${ }^{16}$. Konsep patronase yang dikemukakan Scott lebih tepat diterapkan dalam melihat relasi sosial dalam keluarga Muna, meskipun di sana sini juga terdapat banyak ketidakcocokan.

Menurut Scott, gejala patronase memiliki tiga ciri, pertama, adanya ketidakseimbangan (inequality) dalam pertukaran. Patron berada dalam posisi pemberi barang atau jasa yang sangat diperlukan bagi klien dan keluarganya. Para klien sebaliknya merasa wajib membalas pemberian tersebut. Selama patron masih mampu memenuhi kebutuhan klien yang paling pokok, maka ia tetap menjadi patron, jika tidak maka seorang klien akan melepaskan diri dari hubungan tersebut tanpa adanya sangsi. Kedua adalah bersifat tatap muka. Hubungan patron

\footnotetext{
${ }^{14}$ Smith, D. J. (2004). Burials and Belonging in Nigeria : Rural - Urban. American Anthropologist, 106(3), $569-579$.

${ }^{15}$ James C Scott, 1972. "Patron-Client Politics and Political Change in Southeast Asia". Dalam Jurnal American Political Science Review. 66 (1): 91-113.

${ }^{16}$ Samuel L Popkin, 1979. The Rational Peasant; The Political Economy of Rural Society in Vietnam. Illinois, F Peacock Publisher Inc.
} 
klien adalah hubungan pribadi yang didasari rasa saling percaya, tanpa perjanjian tertulis. Ketiga adalah sifatnya yang luwes dan tidak hanya pada kebutuhan tertentu, tetapi meluas pada kebutuhan-kebutuhan lain ${ }^{17}$. Konsep ini berbeda dengan konsep patronase yang dikemukakan Popkin yang melihat relasi patrin-klien dengan pendekatan ekonomi politik. Popkin melihat bahwa gejala patronase adalah sistem eksploitasi patron terhadap para petani yang membuat para petani sebagai klien merasa tertekan ${ }^{18}$. Konsep patronase yang dikemukakan Scott lebih tepat diterapkan dalam melihat relasi sosial dalam keluarga Muna, meskipun di sana sini juga terdapat banyak ketidakcocokan.

Gejala patronase dapat berkembang dengan baik menurut Scott disebabkan oleh tiga kondisi, yaitu perbedaan (inequality) yang cukup mencolok atas kepemilikan kekayaan; ketidaktersedianya pranata-pranata yang menjamin keamanan individu, baik status maupun kekayaanya; dan ikatan kekerabatan yang tidak lagi bisa diandalkan untuk memberikan perlindungan dan memajukan diri ${ }^{19}$. Dengan demikian, maka unsur yang harus ada dalam relasi patron-klien adalah pemberian patron kepada klienya adalah sesuatu yang berharga, baik dalam bentuk barang dan jasa atau dalam bentuk yang lain. Seorang patron dalam hal ini bisa memberikan kelangsungan hidup kepada klien, perlindungan secara ekonomi dan sosial, atau jaminan relasi-relasi yang baik. Sementara sang klien memberikan pelayanan, pengabdian, bantuan dalam berbagai bentuk. Relasi patron-klien ini bisa muncul dalam hubungan yang remeh sekalipun di mana penanda utamanya adalah saling menguntungkan antara patron dan klien tersebut.

Sistem kekerabatan di Indonesia tergolong masih cukup kental. Namun demikian, sistem kekerabatan juga nyatanya tidak bisa menjadi jaminan bagi interaksi sosial yang lebih kuat. Gejala inilah yang menyebabkan masyarakat mencari alternatif lain dalam relasi sosial, misalnya dalam hubungan patronase ${ }^{20}$. Ahimsa-Putra menjelaskan beberapa kondisi yang memungkinkan terjadinya sistem patronase dalam masyarakat Sulawesi Selatan sebagaimana tesis Scott, misalnya terdapatnya pelapisan kedudukan dan kekayaan yang dianggap sah dan juga ketidakamanan sosial yang menjadikan orang cenderung mencari perlindungan kepada yang lebih kuat ${ }^{21}$. Akan tetapi, Ahimsa-Putra juga mengeritik temuan Scott bahwa justru ikatan kekerabatan yang menumbuhsuburkan relasi parton-klien dalam masyarakat, terutama dalam masyarakat bangsawan.

Penelitian ini adalah penelitian kualitatif dengan menggunakan pendekatan antropologi keluarga. Data dalam penelitian ini berupa relasi dalam keluarga maupun di luar keluarga orang Muna dan makna keluarga bagi masyarakat Muna. Keluarga Muna yang dimaksudkan dalam penelitian ini adalah keluarga Muna yang secara geografis dan demografis, yaitu dalam kategori Koentjaraningrat adalah keluarga inti yang terdiri atas suami istri dan anak ${ }^{22}$ yang tinggal di wilayah administratif Kabupaten Muna, secara genealogis berasal dari ayah dan/atau ibu orang Muna, dan secara kultur masih memegang teguh dan menjalankan tradisi Muna dalam hidup sehari-hari. Sumber data dalam penelitian ini ada dua, yaitu pertama, sumber lisan berupa wawancara dengan para keluarga Muna; dan sumber tertulis berupa hasil observasi (pengamatan) terhadap relasi dalam keluarga dan luar keluarga Muna dan perilaku antara anggota dalam keluarga serta perlakuan di luar keluarga, dan dokumentasi berupa pengambilan foto ataupun video terkait dengan interaksi keluarga Muna satu sama lain dan juga cara

\footnotetext{
${ }^{17}$ James C Scott, 1972. "Patron-Client..., Op Cit

${ }^{18}$ Samuel L Popkin, 1979. The Rational Peasant..., Op Cit.

${ }^{19}$ James C Scott, 1972. "Patron-Client..., Op Cit

${ }^{20}$ Ibid

${ }^{21}$ Heddy Shri Ahimsa-Putra, 2007. Patron \& Klien di Sulawesi Selatan; Sebuah Kajian FungsionalStruktural. Yogyakarta: Kepel Press.

${ }^{22}$ Koentjaraningrat. 1972. Beberapa Pokok Antropologi Sosial. Jakarta: Dian Rakyat.
} 
masyarakat Muna saling membantu dalam upacara daur hidup. Pendekatan antropologi keluarga yang dimaksudkan adalah melakukan wawancara dengan keluarga orang Muna, observasi teradap kehidupan keluarga Muna. Wawancara dilakukan dengan cara indepth interview (wawancara mendalam) terhadap lima keluarga yang meliputi suami dan istri (sebagai patron), orang-orang dalam keluarga Muna, baik yang masih tinggal di dalam rumah maupun tidak (sebagai client). Observasi dilakukan dengan cara observasi partisipasi dimana peneliti menjadi bagian dari relasi dan interaksi yang terjadi, baik antar keluarga maupun di luar keluarga. Peneliti mengikuti pola interaksi dan observasi pada relasi keseharian dan upacara daur hidup untuk mengamati perilaku dan bentuk bantuan yang diberikan pada upacara daur hidup, kepentingan sekolah dan pekerjaan para client. Dokumentasi dilakukan dengan cara merekam foto dan video proses keterlibatan keluarga maupun diluar keluarga dalam membantu sang patrom pada upacara daur hidup.

Wawancara dan observasi dilakukan untuk menghimpun data-data pola kekerabatan dalam keluarga Muna, memetakan relasi-relasi yang terbangun dalam keluarga maupun di luar keluarga, mendata perilaku masing-masing anggota keluarga dan perlakuan di luar keluarga, dan mengidentifikasi makna keluarga bagi orang Muna. Data-data tersebut kemudian dilakukan koding data untuk mendapatkan data-data domain sesuai dengan focus dan tujuan penelitian. Analisis data dilakukan dengan cara kategorisasi data untuk menentukan relasi yang terbangun diantara data, baik relasi korelasional (menghubungkan antara data yang satu dengan data lainnya), kausal (mencari dan menentukan penyebab dan akibat antardata), maupun kontradiksional (mengelompokkan data-data yang nampak bertentangan antara satu dengan yang lain). Data-data penelitian ini dianalisis dengan mengelaborasikan teori sistem kekerabatan Koentjaraningrat dan teori patronase yang dikemukakan oleh James C. Scott dan dikembangkan oleh Ahimsa-Putra.

Penelitian ini menggunakan pendekatan antropologi keluarga dengan memetakan relasirelasi yang terbangun dalam keluarga maupun di luar keluarga, perilaku masing-masing anggota keluarga dan perlakuan di luar keluarga, dan mengidentifikasi makna keluarga bagi orang Muna. Tulisan ini diharapkan dapat memberikan kontribusi keilmuan dalam memetakan relasi kekerabatan tradisional yang berbungkus patronase modern yang mapan pada beberapa aspek saja namun rapuh pada aspek lain yang bekerja atas dasar transaksional. Tulisan ini memberikan implikasi bahwa masyarakat tradisional membutuhkan mekanisme ikatan yang lebih efektif dalam memenuhi kebutuhan sosial budaya mereka di satu sisi, namun juga tuntutan kehidupan modern yang tidak bisa diabaikan dengan relasi-relasi yang lebih terbuka pada sisi yang lain.

\section{B. Kekerabatan dan Patronase Masyarakat Muna}

\section{B.1. Sistem Kekerabatan Patronase Masyarakat Muna}

Masyarakat Muna adalah masyarakat yang menempati wilayah kepulauan Muna, salah satu wilayah Provinsi Sulawesi Tenggara. Ada beberapa kriteria yang bisa dikategorikan sebagai masyarakat Muna. Secara geografis dan demografis, masyarakat Muna adalah masyarakat yang mendiami Kabupaten Muna; secara sosial masyarakat Muna adalah masyarakat yang ayah dan/atau ibunya adalah orang Muna; sedangkan secara kultur, masyarakat Muna mengacu kepada suku bangsa di mana masyarakatnya memegang teguh adat istiadat Muna dan menerapkan adat istiadat tersebut dalam pola hidup keseharian. Dengan demikian yang dimaksudkan dengan masyarakat Muna adalah masyarakat Muna yang secara geografis, demografis, sosial, kultur dan/atau campuran dari unsur-unsur tersebut. 
Keluarga Muna memperhitungkan prinsip bilateral (bilateral descent) yang menghitung hubungan kekerabatan dari garis keturunan laki-laki (ayah) dan perempuan (ibu) ${ }^{23}$. Dengan demikian, maka kekerabatan bilateral masyarakat Muna memungkinkan seseorang memiliki hubungan kekerabatan dari kedua orang tuanya, keempat kakek dan neneknya dan seterusnya ${ }^{24}$.

Dalam masyarakat Muna, garis kekerabatan secara lineal hingga pada empat kakek dan neneknya dan secara lateral sampai pada sepupu tiga kali. Kelompok kekerabatan masyarakat Muna meliputi dua jenis, yaitu keluarga terdekat atau keluarga inti/batih (nucleur family) dan keluarga luas (extended family). Keluarga batih atau keluarga inti dalam masyarakat Muna terdiri atas ayah, ibu, dan anak-anak yang belum menikah. Namun demikian, bisa saja dalam satu rumah tangga tinggal pula beberapa orang di luar keluarga inti, tetapi juga kerabat lain bahkan di luar ${ }^{25}$. Satu rumah tangga (household) menurut Koentjaraningrat ditentukan oleh dapur yang samas sebagai sumber ekonomi. Hal ini sama persis dalam keluarga Bali yang menyebut dengan istilah kuren, artinya rumah tangga atau dapur. Dalam masyarakat Muna, rumah tangga disebut dengan lambu. Maka, jika dalam masyarakat Muna terdapat beberapa keluarga inti yang hanya terdapat satu dapur yang dikelola bersama, maka keluarga tersebut tetaplah disebut satu rumah tangga atau satu lambu.

Keterlibatan kerabat dan orang-orang yang memiliki relasi sosial lain diluar kerabat akan terlihat dalam perayaan upacara masyarakat Muna yang biasa dirayakan secara meriah dan melibatkan banyak orang. Upacara ini juga menjadi ajang berkumpul dan silaturahmi para keluarga, saudara, tetangga, teman dan relasi.

Dalam masyarakat tradisional atau yang tinggal di desa-desa, kerja sama dan solidaritas yang terbangun adalah solidaritas mekanik. Berbeda dengan masyarakat industrial perkotaan, dimana solidaritas yang terbangun adalah solidaritas organik. Karakteristik solidaritas mekanik dicirikan oleh (1) pembagian kerja yang rendah; (2) kesadaran kolektif yang kuat; (3) hukum represif yang dominan; (4) konsensus terhadap pola-pola normatif dianggap sangat penting; (5) sistem individualitas yang rendah; (6) komunitas terlibat dalam menghukum orang yang dianggap menyimpang; (7) saling ketergantungan yang relatif rendah; dan (8) bersifat primitif atau biasa terjadi dalam masyarakat pedesaan ${ }^{26}$.

Dalam relasi patronase, seorang patron yang menyelenggarakan upacara daur hidup, para klien akan datang memberikan bantuan dan pelayanan secara otomatis, meski tanpa diundang. Jika relasi patronase terjalin dalam sistem kekerabatan, maka bantuan yang datang secara otomatis tersebut akan lebih kuat lagi. Ketidakhadiran seorang kerabat atau relasi sosial dalam acara-acara tersebut akan menimbulkan cemoohan dan gunjingan oleh kerabatnya yang lain. Jika kerabat yang tidak peduli dengan kerepotan kerabatnya tersebut mengadakan acara atau hajatan, maka biasanya orang-orang atau kerabat juga akan enggan untuk datang membantu atau menghadiri. Teori reciprocity dan gift dalam kasus demikian agaknya masih sangat menguat, baik dalam masyarakat tradisional bahkan dalam masyarakat modern sekalipun $^{27}$, sebagaimana juga yang ditemukan dalam masyarakat Muna sebagaimana dalam tulisan ini.

${ }^{23}$ Koentjaraningrat. 1972. Beberapa Pokok Antropologi Sosial. Jakarta: Dian Rakyat.

${ }^{24}$ Haviland. 1999. Cultural Anthropology. New York: Harcourt Brace College Publisher, hlm. 303.

${ }^{25}$ Koentjaraningrat. 1972. Beberapa Pokok..., Op Cit, hlm. 104.

${ }^{26}$ Paul D Johnson, 1994. Teori Sosiologi: Klasik dan Modern, Jilid I dan II, Terj. Robert M.Z. Lawang. Gramedia: Jakarta.

${ }^{27}$ Marcell Maus, 1994. The Gift, Form and Function Echange in Archaic Societies, Terjem. Jakarta: Yayasan Obor Indonesia; Aaefke Komter, 2005. Social Solidarity and The Gift. New York: Cambridge University Press; lihat juga Alvin W Gouldner, 1997. "The Norm of Reciprocity: A Prilimi- nary Statement, " dalam Ramlan Surbakti, ed., Teori Teori Sosial Mikro. Surabaya: Unair. 
Penyelenggaraan upacara daur hidup dengan mengumpulkan keluarga bisa menciptakan rasa identitas, rasa memiliki dan solidaritas ${ }^{28}$. Ketika masyarakat sudah mulai hijrah ke kota dan pengaruh modernitas tak bisa dibendung, masyarakat Muna tidak melupakan tradisi untuk menyelenggarakan upacara atau tradisi lokalnya. Upacara yang diselenggarakan pada waktuwaktu yang pas untuk berkumpul, seperti setelah lebaran idul fitri menjadi kesempatan bagi setiap individu untuk mengikatkan kembali ikatan kekeluargaan. Tidak hanya kerabat, orang lain yang memiliki keterikatan emosional dan sosial juga biasanya diajak dan menjadi peserta dalam upacara yang diselenggarakan secara bersama-sama. Bahkan, upacara yang diselenggarakan secara kolektif semakin menguatkan dan menegaskan kembali ikatan kekeluargaan yang diikat tidak hanya oleh darah dan perkawinan, tetapi juga ikatan sosial dan emosional yang membungkus hubungan patronase.

Dalam ikatan kekeluargaan yang diikat secara genalogis dan sosial, rujukan dan panggilan kekerabatan menjadi lebur dalam sistem keluarga besar yang lebih longgar. Untuk menjelaskan hal tersebut, peneliti menuliskan nama subjek penelitian dengan inisial atas izin yang bersangkutan. Salah satu subjek penelitian, yaitu LM dipanggil dengan kata "Bapak" oleh "anak-anak tinggal", kerabat, maupun para klien baik dalam term of reference (istilah untuk menyebut) maupun dalam term of address (istilah untuk menyapa ${ }^{29}$. Salah seorang cucu kemenakan LM, yaitu FR menjelaskan bahwa "biasanya kami selalu panggil Bapak, meskipun dia bukan kita punya bapak tapi sebetulnya kan kakeknya bapaku. Tapi karena bapaku panggilnya juga Bapak maka kita juga panggil bapak" ${ }^{30}$. Fakta ini dalam term Harris disebut sebagai penyebutan "father" secara kultural. Harris menjelaskan bahwa harus bisa dibedakan antara sebutan ayah "father" secara kultur dengan seorang yang disebut "genitor" sebagai seorang ayah biologis ${ }^{31}$. Sebutan ayah bisa dirujuk oleh siapapun tidak hanya sang anak keturunan biologis tetapi juga sosial. Keterlibatan LM secara kultur juga dapat dilihat dari penyelesaian pertentangan dalam prosesi lamaran dan pembicaraan uang adat, konflik-konflik perkawinan atau pertentangan yang terjadi di antara keluarga. Setiap perkawinan yang melibatkan kerabat luas dan orang-orang dari desa asal, selama ia bertempat tinggal di Sulawesi Tenggara hampir selalu melibatkan LM dan keluargnya. Hajat atau upacara daur hidup yang diselenggarakan LM dan keluarganya juga selalu mendatangkan bantuan dari kerabat yang lain maupun para klien secara langsung dan otomatis. Tidak hanya terjadi pada LM, relasi kekerabatan patronase juga terjadi pada anak-anak LM. Acara-acara hajatan yang dilakukan oleh anak-anak LM juga selalu mengundang berkumpulnya para kerabat dan para klien secara otomatis.

Demikian halnya dengan LD. Kesuksesanya di kota Raha dan akhirnya pindah ke Kendari menjadikan dirinya menjadi rujukan bagi orang-orang kampung, sehingga lama kelamaan ia menjadi patron bagi keluarga dan orang-orang kampung. Posisinya sebagai patron akhirnya membuat dia dianggap sebagai "orang tua" dan tokoh masyarakat. Posisi LD sebagai patron bukan bersifat pemberian materi secara langsung, tetapi bersifat jangka panjang dan dalam hal-hal yang substantif. Patronase yang dimilikinya tidak bersifat praktis, tetapi menyasar pada relasi yang lebih luas dan langgeng. Kekuatan patronase yang dimilikinya juga tidak hanya milik dirinya sendiri tetapi juga dimiliki dan diwarisi oleh anak-anaknya. Inilah yang ikut melanggengkan posisi patronase yang dimiliki LD dan keluarga besarnya.

Fakta ini menunjukan bahwa orang-orang rantau jika sukses di kota atau di daerah lain, dapat memiliki potensi untuk menjadi patron bagi kerabat, keluarga atau orang lain yang

\footnotetext{
${ }^{28}$ Grace M Viere, 2001. "Examining Family Ritual”. The Family Jounal. 9, Juli: 285-288.

${ }^{29}$ Koentjaraningrat. 1972. Beberapa Pokok..., Op Cit, hlm. 137.

${ }^{30}$ Wawancara, FR, 12 Mei 2018.

${ }^{31}$ Ibid.
} 
memerlukan bantuan dan perlindungannya. LJ, seorang pegawai negeri yang pernah tinggal bersama dengan keluarga LG menuturkan sebagai berikut:

"Dulu waktu saya masih sekolah di Raha dirumahnya Pak LD, saya ingat betul banyak sekali orang yang tinggal dirumahnya. Semuanya dari kampong dan disekolahkan oleh dia. Kami kalau makan berjejer seperti tentara mau makan. Saya tidak tahu dari mana itu rezeki tetapi selalu saja makanan cukup untuk kami makan padahal banyaknya mi itu orang tinggal" 32

Rumah LD menurut penuturan LJ di atas menjadi rujukan orang-orang desa yang datang untuk sekedar mampir karena tidak memiliki rumah atau keluarga sebagai tempat menginap, menitipkan sekolah anak-anak dari keluarga di kampung atau yang ikut membantu pekerjaan di rumah tersebut. Para patron ini ketika pulang kampung biasanya menyelenggarakan upacara daur hidup secara kolektif dengan mengajak kerabat, keluarga, tetangga atau siapapun yang ingin ikut bersama-sama dalam upacara. Dalam hal ini ia menjadi penanggung jawab atau pokok bagi penyelenggaraan upacara. Posisinya sebagai pokok atau penanggung jawab dalam pelaksanaan upacara menegaskan dan menguatkan posisinya secara sosial sebagai orang rantau yang sukses. Ini sekaligus juga menjadi penegas patronasenya dan menjadi nilai dan prestise sosial yang kuat.

Ketergantungan sosial dan ekonomi menyebabkan terbentuknya hubungan sosialemosional, terutama oleh klien kepada patronnya. Sebaliknya, sang patron membutuhkan bantuan dan pelayanan para klien untuk memelihara kedudukan sosialnya. Hubungan sosial, ekonomi, dan emosional tersebut menyebabkan para klien, baik yang masih memiliki hubungan kerabat atau tidak dianggap sebagai keluarga meskipun ada di antaranya yang tidak memiliki hubungan darah, sehingga acara-acara yang diselenggarakan oleh rumah tangga tersebut akan melibatkan mereka secara otomatis.

\section{B.2. Relasi Tarik Menarik antara Kekerabatan dan Patronase}

Gejala patronase dalam studi ini dikaji dengan teori yang dikemukakan oleh Scott yang juga telah banyak dikritik dan dielaborasi oleh Ahimsa-Putra. Menurut Scott, gejala patronase memiliki ciri-ciri sebagai berikut: pertama, adanya ketidakseimbangan (inequality) dalam pertukaran. Patron berada dalam posisi pemberi barang atau jasa yang sangat diperlukan bagi klien dan keluarganya. Para klien sebaliknya merasa wajib membalas pemberian tersebut. Selama patron masih mampu memenuhi kebutuhan klien yang paling pokok, maka ia tetap menjadi patron, jika tidak maka seorang klien akan melepaskan diri dari hubungan tersebut tanpa adanya sangsi. Kedua adalah bersifat tatap muka. Hubungan patron klien adalah hubungan pribadi yang didasari rasa saling percaya, tanpa perjanjian tertulis. Ketiga adalah sifatnya yang luwes dan tidak hanya pada kebutuhan tertentu, tetapi meluas pada kebutuhankebutuhan lain ${ }^{33}$. Konsep ini berbeda dengan konsep patronase yang dikemukakan Popkin yang melihat relasi patrin-klien dengan pendekatan ekonomi politik. Popkin melihat bahwa gejala patronase adalah sistem eksploitasi patron terhadap para petani yang membuat para petani sebagai klien merasa tertekan ${ }^{34}$. Konsep patronase yang dikemukakan Scott lebih tepat diterapkan dalam melihat relasi sosial dalam keluarga Muna, meskipun di sana sini juga terdapat banyak ketidakcocokan.

Jalinan kekerabatan maupun patronase bekerja dan mempengaruhi kehidupan masyarakat, baik secara sosial maupun kultur. Baik jalinan kerabat maupun relasi patronase sama-sama memiliki potensi untuk menguat atau melemah. Kedua jalinan sosial tersebut tergantung pada dua hal, yaitu pertama, sesuatu yang diterima oleh masing-masing pihak adalah

\footnotetext{
${ }^{32}$ Wawancara dengan LJ, 10 Maret 2018

${ }^{33}$ James C Scott, 1972. "Patron-Client..., Op Cit

${ }^{34}$ Samuel L Popkin, 1979. The Rational Peasant.... Op Cit
} 
sesuatu yang sangat berharga dan dibutuhkan; dan kedua adalah terpenuhinya kebutuhan dan kepentingan masing-masing pihak ${ }^{35}$.

Jalinan kerabat secara kultur mestinya berkonsekwensi pada kepedulian anggota kerabatnya. Ikatan tersebut tersimpul oleh karena ikatan darah lewat keturunan dan perkawinan. Namun demikian, ikatan kekerabatan dapat terburai secara emosional dan sosial, meskipun secara kultur-genealogis tetap terikat. Ikatan kekerabatan lebih bersifat langgeng, emosional, dan tidak langsung. Seorang kerabat yang acuh tak acuh dan mengabaikan kepentingan atau kerepotan kerabatnya yang lain akan dianggap sebagai kerabat yang sombong dan mementingkan diri sendiri. Dalam pertemuan-pertemuan keluarga besar, ia akan dicemooh dan diguncingkan meskipun masih tetap diundang untuk menghadiri acara-acara yang dihadiri oleh kerabatnya yang lain, terutama jika ia adalah seorang pejabat. LT dan ST misalnya adalah dua kasus keluarga Muna yang berhasil di kota Raha dan kota Kendari. LT adalah seorang pensiunan pejabat di kota Raha dan SA adalah seorang pejabat aktif di kota Kendari. Akan tetapi keduanya tidak dapat menjadi patron, meskipun ia memiliki modal sosial dan ekonomi yang lebih tinggi dari kerabatnya atau dari orang lain. Kerena keduanya tidak dapat memenuhi kebutuhan sosial dan emosional kaum kerabatnya, maka mereka tidak dapat menjadi patron bagi kaum kerabatanya atau orang lain.

Bagi keluarga besarnya, LT dan anak-anaknya meskipun berhasil secara ekonomi dan sosial akan tetapi tidak terlalu dekat dengan kerabat lainnya. Ada jarak yang memisahkan keluarga LT dengan keluarga lainnya. Acara-acara yang diselenggarakan oleh kerabatnya di desa jarang dihadirinya. Cerita beberapa kerabat dekatnya mengatakan bahwa mereka seolah menjaga jarak dengan orang-orang yang dianggap bukan berasal dan level sosial yang sama dengan mereka. Bagi orang-orang kampung di desanya, keluarga LT memang masih terhitung sebagai keluarga, tetapi mereka dianggap bukan keluarga. Istilah yang sering terdengar adalah "keluarga tapi bukan keluarga". Ungkapan ini banyak didapatkan dalam interaksi dengan para keluarga Muna, baik dalam pergaulan sehari-hari maupun dalam perayaan-perayaan acara keluarga besar orang Muna. Ikatan kekerabatan yang terjalin di dalamnya tidak mungkin bisa dihindari, akan tetapi secara sosial, para kerabat tersebut tidak lagi dianggap sebagai keluarga. Kasus lain adalah keluarga SA, seorang pejabat di Pemrov Sulawesi Tenggara yang meskipun mapan secara ekonomi dan sosial, tidak bisa diandalkan untuk dimintai tolong menolong kerabatnya. Namun demikian, sikap ketidakpedulian terhadap kepentingan kerabatnya tidak akan sampai memutuskan hubungan kekerabatan secara kutur-genalogis. Sehingga, sekalipun ada anggota kerabat yang menunjukan sikap acuh tak acuh pada kerabat lainnya sebagaimana kasus LT dan SA, tetaplah menjadi bagian dari kerabat.

Akan tetapi dalam relasi patronase, ikatan yang terjalin bersifat kontraktual oleh sebab ikatannya dihubungkan oleh kepentingan yang terpenuhi antara masing-masing pihak secara praktis. Seorang patron bisa saja menarik banyak klien jika ia mampu memenuhi kebutuhan kliennya, sebagaimana dalam kasus LM dan keluarganya. Akan tetapi bagi orang lain yang memiliki kepentingan yang lain tidak dapat menjadi klien bagi patron yang bersangkutan atau bisa saja menjadi klien dan memilih patron yang lain. Begitu pula halnya seorang klien dapat saja berpindah patron atau berhenti menjadi klien bagi patron tertentu. ikatan patronase akan lebih mudah terburai jika masing-masing pihak tidak lagi dapat memenuhi kepentingan dan kebutuhan pihak lainnya. Ikatan yang dimilikinya bersifat praktis, kontraktual, dan langsung. Ikatan patronase lebih bersifat sosial yang langsung dirasakan akibatnya secara sosial pula.

Kasus kepedulian atau ketidakpedulian terhadap kerabat secara antropologis dapat dijelaskan dengan melihat pengetahuan seseorang terhadap kerabat sosiologis. Pengetahuan akan batas kerabat sosiologis ditentukan oleh tiga kategori, yaitu batas kesadaran kekerabatan

\footnotetext{
${ }^{35}$ Heddy Shri Ahimsa-Putra, 2007. Patron \& Klien..., Op Cit
} 
(kingship awareness), batas pergaulan kekerabatan (kingship affiliations), dan batas hubunganhubungan kekerabatan (kingship relations) ${ }^{36}$. Batas kesadaran kekerabatan (kingship awareness) adalah kesadaran seseorang untuk mengenal para kerabatnya. Batas pergaulan kekerabatan (kingship affiliations) adalah sejauh mana dia mengenal dan mau bergaul dengan kerabatnya. Batas hubungan kekerabatan (kingship relations) ditentukan oleh proses seleksi dalam menganggap yang mana kerabat yang pantas diakuinya atau diperlakukan sebagai kerabat dan mana yang tidak. Keluarga LT dan SA sebagaimana kasus di atas, boleh jadi mengetahui dan menyadari sejauh mana ikatan keluarga dengan para kerabatnya, akan tetapi yang banyak berperan adalah batas hubungan kekerabatan, dimana meskipun masih terikat dalam keluarga, akan tetapi dengan siapa keluarga LT dan SA akan bergaul dan memperlakukan kerabatnya dengan baik sudah melalui proses seleksi. Maka, yang terjadi adalah tidak semua kerabat mendapatkan perlakuan yang sama oleh keluarga SA dan LT. Sebaliknya, dalam kasus keluarga LM, ketiga kategori tersebut (batas kesadaran kekerabatan, batas pergaulan kekerabatan, dan batas hubungan kekerabatan) berjalan dengan porsi yang seimbang.

Relasi kekerabatan patronase pada ranah sosial (pendidikan dan budaya) dapat dikatakan berpengaruh secara signifikan pada ranah budaya (penyelenggaraan upacara daur hidup). Para kerabat atau para klien yang mendapatkan jaminan pendidikan dan pekerjaan dari LM sebagai patron mendedikasikan tenaga dan pikirannya pada perayaan hajatan atau upacara daur hidup yang diselenggarakan keluarga besar LM. Sebaliknya. Patron, dalam hal ini LM dan anak-anaknya mengajak para kerabat dan para klien untuk bersama-sama dalam acara penyelenggaraan upacara daur hidup. Sebagaimana terjadi pada perayaan katoba (upacara inisiasi kedewasaan anak) yang diselenggarakan secara meriah dan melibatkan banyak orang pada tanggal 1 Juli 2019 yang lalu. Anak-anak yang ikut dalam upacara tersebut sebanyak 38 anak yang merupakan anak-anak para kerabat dan klien LM dan anak-anaknya. Keikutsertaan para kerabat dan para klien secara serentak pada acara tersebut juga memperhitungkan keringanan biaya, kerepotan, dan pekerjaan dibandingkan dengan jika menyelenggarakan acara sendiri untuk anak-anak mereka.

Secara umum, ikatan kekerabatan menjadi garansi bagi jalinan kepentingan kolektif secara serentak. Namun, hal ini tidak berlaku dalam pilihan politik. Seorang kerabat yang adalah seorang patron tidak otomatis akan didukung oleh kerabat atau kliennya, terutama dalam pilihan politik. Kasus ini terjadi dalam proses pemilihan anggota legislatif pada tahun 2014 lalu. LM adalah patron bagi kerabatnya dan juga bagi orang lain. Modal sosial ini awalnya dipercaya akan dapat meraup suara konstituen dalam pemilihan anggota legislatif pada pemilu 2014 lalu. Daerah pemilihan LM berada di wilayah yang banyak kerabat dan orang-orang yang menjadi kliennya. Akan tetapi, hasil pemungutan suara sangat mengecewakan, sebab kantong-kantong suara yang diperkirakan akan penuh dengan banyaknya suara kerabat, justru tidak memenuhi standar. Para kerabat mengalihkan suaranya pada calon lain yang memberikan uang lebih banyak. LM pada saat itu memang tidak memiliki modal sebanyak yang dimiliki kandidat lain. Ia hanya mengandalkan harapan bahwa kaum kerabat dan orang-orang yang pernah ditolongnya akan dengan sukarela memberikan suara padanya. Tidak hanya ikatan kekerabatan yang diandalkanya, tetapi juga keyakinan kuat sebab menurut ceritanya dan cerita beberapa warga desa, ia banyak memberikan bibit pohon nilam secara gratis bagi desa-desa tetangga yang menjadi daerah pemilihan jauh beberapa tahun sebelumnya. Tanaman nilam tersebutlah yang sedikit banyak merubah dan meningkatkan tingkat pendapatan warga desa. Sayangnya anggapan LM bahwa kampanye dan sosialisasi yang dilakukannya yang dinggapnya lebih efektif jauh sebelum para calon lain tidak terbukti. Kerabat atau seorang klien tidak menutup kemungkinan akan meninggalkan kerabat atau patronnya jika ia merasa kepentinganya sudah

\footnotetext{
${ }^{36}$ Koentjaraningrat. 1972. Beberapa Pokok..., Op Cit, hlm. 127.
} 
selesai dan telah terpenuhi atau sang patron tidak lagi dapat memenuhi keinginanya, sebagaimana kasus para klien LM pada masa pemilihan calon anggota legislatif pada pemilu 2014 silam. Kasus ini berbeda dengan studi Purwaningsih dimana Pilkada langsung menunjukan adanya politik kekerabatan di Sulawesi Selatan pada periode 2009-2014 yang memberikan kesempatan lebih besar kepada keluarga politik untuk memperoleh atau memperbesar kekuasaannya ${ }^{37}$. Meskipun indeks kualitas kandidat dari keluarga politik cenderung menurun. Hal ini dipengaruhi oleh semakin mudanya usia kandidat untuk memperoleh kekuasaan karena adanya peluang yang diberikan oleh partai-partai politik baru. Bagaimanapun, sistem norma sosial yang dilandasi oleh bangunan moralitas yang luhur sekalipun dapat saja terurai sebab ikatan demikian bergantung pada kematangan dan kedewasaan moral para pihak yang terlibat, dimana hati nurani menjadi faktor penentu bagi berlangsungnya relasi yang terjadi ${ }^{38}$.

Kasus di atas menunjukan bahwa interaksi diantara kerabat dan antara patron dan klien dalam aspek pendidikan, ekonomi, dan budaya masih cukup aman. Pada aspek politik, terlebih dalam preferensi politik, ikatan tersebut menjadi melemah oleh karena kepentingan praktis dan pragmatis. Relasi yang diikat oleh hubungan emosional yang kuat sekalipun dalam banyak penelitian nyatanya dapat melemah ketika sudah bersentuhan dengan ranah politik. Dalam institusi pesantren, misalnya ketertundukan santri pada kiyai mulai berkurang oleh sebab bergesernya peran kiyai yang semula berbalur kharismatik namun berubah total ketika memasuki dunia politik, sebagaimana penelitian Turmudi ${ }^{39}$; Zamroni ${ }^{40}$; Setiawan ${ }^{41}$.

Kedekatan dengan kerabat lebih banyak dikuatkan oleh ikatan emosional berupa kepedulian akan masalah-masalah sosial. Sementara patronase lebih banyak dikuatkan oleh kepentingan praktis dan pragmatis. Kedekatan emosional dengan kerabat saja nyatanya bisa terburai oleh karena faktor ekonomi dan mental manusia, maka ikatan praktis dan pragmatis patronase akan lebih lemah dan rentan. Dalam kasus ini, dapat dikatakan bahwa relasi kekerabatan patronase bukanlah jalinan yang mapan dan langgeng, ia masih bersifat rentan dan pragmatis, sebab meskipun kekerabatan tetap ada tetapi yang hadir adalah ikatan kekerabatan palsu dan mudah goyah (pseudo kingship).

Dengan demikian, sistem kekerabatan dan sistem patronase, serta sistem kekerabatan patronase memiliki kekuatan dan kelemahan sekaligus. Ada kondisi-kondisi tertentu yang menguatkan atau melemahkan jalinan tersebut. Sistem kekerabatan patronase akan menguat manakala pertama keinginan dan kebutuhan masing-masing pihak antara patron dan klien dapat dipenuhi satu sama lain; kedua kepentingan masing-masing pihak antara patron dan klien berjalan seiring. Sebaliknya, jalinan sistem kekerabatan patronase akan melemah pada kondisikondisi sebagai berikut; pertama, keinginan dan kebutuhan satu pihak (misalnya patron atau klien) tidak dipenuhi pihak lainnya; kedua tidak ada lagi yang dibutuhkan dan diharapkan dari masing-masing pihak (patron atau klien); ketiga kasus yang parah adalah jika salah satu pihak tidak dapat menjaga komitmen ikatan, misalnya klien mengkhianati patron atau sebaliknya patron mengabaikan klien.

Sistem kekerabatan patronase berada dalam kondisi tarik menarik dan masih belum mapan, ia mengikuti dinamika karakter sosial masyarakat tempat interaksi tersebut berlangsung. Relasi kekerabatan patronase ini berimplikasi pada kemapanan sistem dan struktur sosial masyarakat Muna. Jika relasi yang sudah dibangun secara kultur lewat relasi kekerabatan dan dikuatkan secara sosial lewat relasi patronase mestinya akan lebih memapankan sistem

\footnotetext{
${ }^{37}$ Titin Purwaningsih, 2015. "Politik Kekerabatan..., Op Cit.

${ }^{38}$ Supartiningsih, 2010. “Konsep Ajjoareng-Joa' ..., Op Cit, hlm. 236

${ }^{39}$ Endang Turmudi, 2003. Perselingkuhan Kiyai dan Politik. Jakarta: LP3ES.

${ }^{40}$ Zamroni, Imam. 2007. "Kekuasaan Juragan Dan Kiai Di Madura”, Jurnal Karsa. XII (2): 168-179.

${ }^{41}$ Eko Setiawan, 2012. "Eksistensi Budaya..., Op Cit.
} 
dalam banyak aspek, baik aspek sosial, budaya maupun politik. Akan tetapi, struktur tersebut masih dapat ditemukan relatif rentan dan goyah, terutama dalam ranah politik. Dengan demikian, relasi yang terbangun secara sosial dan kultur masih belum menjamin tatanan sosial secara lebih mapan. Hal ini berbeda dengan temuan Hefni dalam penelitiannya di masyarakat Madura dimana relasi patronase berlangsung dalam hubungan unggul-asor (superiorsubordinate). Sekali seorang patron menjadi patron, maka hubungan dengan para klien berlangsung lama. Ikatan ini dilandasi oleh bentukan hubungan diadik (dwitunggal), suatu hubungan yang bersifat pribadi yang bermula dari hubungan ekonomi. Konsekwensinya, jika sang patron terlibat dalam politik, maka para pengikut (klien) berkewajiban untuk mengerahkan dan menyediakan hak suara atau bahkan merelakan jiwa demi kepentingan sang patron ${ }^{42}$.

Tulisan ini menegaskan bahwa patronase bisa bekerja dalam sistem kekerabatan dan sebaliknya sistem kekerabatan tidak sepi dari gejala patronase. Sebagaimana juga yang ditemukan dalam penelitian Ahimsa-Putra dan Smith. Tesis ini ditegaskan Ahimsa-Putra dalam masyarakat Sulawesi Selatan bahwa hubungan kekerabatan justru menguatkan gejala patronase dalam masyarakat tersebut dan bukan malah melemahkan sebagaimana tesis Scott. Relasi patron-klien yang terjadi dalam masyarakat Sulawesi Selatan menurut Ahimsa-Putra sangat nyata dan kuat ditemukan dalam masyarakat bangsawan yang merupakan status yang diperoleh berdasarkan keturunan. Temuan ini mengkitik tesis Scott bahwa patronase tidak akan bekerja dalam sistem kekerabatan. Temuan ini mengkitik tesis Scott bahwa patronase tidak akan bekerja dalam sistem kekerabatan.

Bagaimanapun, penelitian ini memberikan pemahaman bahwa relasi-relasi tradisional yang hanya dihubungkan secara kerabat tidak cukup mapan dalam masyarakat modern. Masyarakat tradisional sebagaimana halnya Muna memiliki ekspektasi dan kebutuhan modern yang memerlukan penyelesaian dan pemenuhan kebutuhan secara praktis dan pragmatis. Oleh sebab itu, boleh jadi relasi yang terbangun menjadi relasi transaksional. Namun demikian, relasi tradisional sebagaimana halnya kekerabatan masih sangat dibutuhkan dalam aspek-aspek yang membutuhkan kebersamaan komunal. Sebaliknya dalam masyarakat yang lebih luas kekerabatan patronase sangat signifikan diperlukan demi memenuhi kebutuhan masyarakat. Penelitian ini berimplikasi pada relasi-relasi yang tidak mapan diantara masyarakat, meskipun diikat oleh hubungan kekerabatan biologis. Jika kekerabatan biologis saja dapat terburai, maka relasi patronase bisa saja juga terurai ketika persyaratan patronase tidak terpenuhi antara sang patron dan klienya.

Pada akhirnya, masyarakat Muna terus bergerak dan berubah tergantung karakteristik secara internal dan dinamika perubahan secara eksternal. Barangkali dalam masa-masa mendatang, ketika karakter masyarakatnya telah berubah lebih mapan, maka eksistensi kamapanan sistem tersebut akan dapat dicapai. Sistem kekerabatan atau sistem patronase ataupun kekerabatan patronase yang berhubungan secara signifikan dengan kemapanan masyarakat tergantung pada karakteristik masyarakat. Boleh jadi lokus masyarakat lain memiliki ciri khas berbeda (barangkali dengan sistem kekerabatan yang lebih luas) akan dapat menunjukan relasi kekerabatan patronase yang lebih mapan. Untuk membuktikan asumsi ini tentu saja diperlukan penelitian lebih lanjut.

\section{Penutup}

Relasi keluarga Muna diikat secara sosial dan kultur oleh dua simpul, yaitu relasi kerabat dan relasi patronase. Dua simpul tersebut menyatu dalam ikatan yang disebut sistem kekerabatan patronase. Baik ia kerabat maupun bukan kerabat, jika ia sudah terjalin dalam relasi sosial yang bersifat emosional, maka simpul tersebut memberi hak pada semua orang untuk

\footnotetext{
${ }^{42}$ Moh Hefni, 2009. "Patron-Client Relationship Pada Masyarakat Madura", Jurnal Karsa. XV (1), April: $15-24$.
} 
dianggap dan diperlakukan sebagai kerabat, baik ia masih memiliki hubungan darah keturunan (descent/consanquity) atau perkawinan (afinity); ataupun yang memiliki relasi sosial lain dalam hubungan patronase/klientisme. Relasi-relasi sosial tersebut menyatukan keluarga Muna dalam relasi kultur yang disebut dalam istilah lokal intaidi bhasitie (kita adalah keluarga). Ia mestinya lebih langgeng dari pada sekedar hubungan kekerabatan atau hubungan patronase, sebab ia diikat oleh dua jaringan sosial dan budaya sekaligus. Perayaan tradisi daur hidup dalam masyarakat Muna menjadi media penyatuan dan berkumpulnya kembali para kerabat dan klien dalam satu solidaritas mekanik yang berlangsung secara otomatis. Hubungan kekerabatan patronase ini makin menguatkan perayaan tradisi upacara daur hidup secara kolektif yang melibatkan banyak orang.

Dalam masyarakat Muna, kekuatan dan kelemahan jalinan yang terjadi masih belum aman dan mapan. Selain itu, dalam masyarakat Muna, seorang patron tidak harus seorang bangsawan. Ia bisa jadi hanya seorang pegawai negeri, wiraswasta, pedagang, pengusaha kecial, atau penguasa yang dianggap sukses yang tidak berhubungan dengan kategori bangsawan atau bukan bangsawan. Bagaimanapun, studi ini menegaskan bahwa jalinan sistem kekerabatan yang dibungkus oleh relasi patronase atau sebaliknya jalinan patronase yang dikuatkan dengan relasi kekerabatan masih bisa goyah. Ia bisa saja aman pada aspek-aspek sosial tertentu (pendidikan dan ekonomi) dan budaya (upacara daur hidup), tetapi bisa melemah pada aspek sosial lainnya (preferensi politik).

Sistem kekerabatan maupun patonase bisa saja menguat atau melemah tergantung relasi yang dibangun dan kepentingan satu sama lain para pemilik kerabat atau patronase tersebut. Oleh sebab itu, relasi kekerabatan maupun relasi patronase adalah hubungan yang secara sosial dan kultur bersifat sementara, bukan relasi yang berlangsung selamanya, tergantung pada pemenuhan kepentingan masing-masing pihak yang terlibat di dalamnya. Relasi kekekerabatan akan semakin menguat jika masing-masing kerabat menyadari peran dan fungsi kekerabatannya. Sementara relasi patronase juga akan semakin menguat jika kepentingan patron di satu sisi dan kepentingan klien di sisi lain saling terpenuhi dan berterima satu sama lain.

Penelitian ini masih sebatas mengeksplorasi relasi kekerabatan patronase pada dua aspek kehidupan masyarakat Muna, yaitu aspek social dan aspek ekonomi. Relasi kekerabatan yang berbungkus patronase pada masyarakat Muna mendapatkan tantangan pada aspek politik. Oleh sebab itu, perlu dilakukan riset lanjutan pada aspek politik untuk menguji kemapanan atau malah kerentanan relasi kekerabatan patronase; apakah masih menjadi ikatan yang solid atau malah tercerai berai oleh kepentingan pragmatis.

\section{Daftar Pustaka}

Adams, Carl, and Andreas Neef. 2019. "Patrons of Disaster: The Role of Political Patronage in Flood Response in the Solomon Islands." World Development Perspectives 15 (August). https://doi.org/10.1016/j.wdp.2019.100128.

Ahimsa-Putra, Heddy Shri. 2007. Patron \& Klien di Sulawesi Selatan; Sebuah Kajian Fungsional-Struktural. Yogyakarta: Kepel Press.

Akhtar, Aasim Sajjad. 2011. "Patronage and Class in Urban Pakistan: Modes of Labor Control in the Contractor Economy." Critical Asian Studies 43 (2): 159-84. https://doi.org/10.1080/14672715.2011.570565.

Anwar, Muhammad Fiaz. 2018. "Patronage and Political Affiliation: Case Study of Village Jhok Bodo, District Dera Ghazi Khan, West Punjab" 98-116.

Beresford, Alexander. 2015. "Power, Patronage, and Gatekeeper Politics in South Africa." African Affairs 114 (455): 226-48. https://doi.org/10.1093/afraf/adu083. 
Chandavarkar, Sumeeta Shyamsunder. 1997. "Patron-Client Ties and Maoist Rural China", Thesis MA pada Departmen of Political Science, University of Toronto.

Corstange, Daniel. 2018. "Kinship, Partisanship, and Patronage in Arab Elections." Electoral Studies 52: 58-72. https://doi.org/10.1016/j.electstud.2018.01.006.

Davies, Peter (eds.). 1977. The American Heritage Dictionary of The English Language. New York: Dell Publishing Co., Inc.

Eilenberg, Michael. 2012. "The Confession of a Timber Baron: Patterns of Patronage on the $\begin{array}{lllll}\text { Indonesian-Malaysian } \quad \text { Border." } & \text { Identities } & 19 & \text { (2): }\end{array}$ https://doi.org/10.1080/1070289x.2012.672841.

Ferrol-Schulte, Daniella, Sebastian C.A. Ferse, and Marion Glaser. 2014. "Patron-Client Relationships, Livelihoods and Natural Resource Management in Tropical Coastal Communities." Ocean and Coastal Management 100: 63-73. https://doi.org/10.1016/j.ocecoaman.2014.07.016.

Flammini, Roxana. 2010. "Elite Emulation and Patronage Relationships in the Middle Bronze: The Egyptianized Dynasty of Byblos." Tel Aviv 37 (2): 154-68. https://doi.org/10.1179/033443510x12760074471026.

Gouldner, Alvin W. 1997. "The Norm of Reciprocity: A Prilimi- nary Statement, " dalam Ramlan Surbakti, ed., Teori Teori Sosial Mikro. Surabaya: Unair.

Harris, Marvin. 1997. Culture, People, Nature; an Introduction to General Anthropology. New York: Longman.

Haviland. 1999. Cultural Anthropology. New York: Harcourt Brace College Publisher.

Hefni, Moh. 2009. "Patron-Client Relationship Pada Masyarakat Madura", Jurnal Karsa. XV (1), April: 15-24.

Hidayat, Ade. 2017. "Pola Pewarisan Nilai Yang Berimplikasi Bimbingan Pada Pancakaki Bani Nurya", JOMSIGN: Journal of Multicultural Studies in Guidance and Counseling. 1 (1), Maret: 99-122.

Javid, Hassan. 2011. "Class, Power, and Patronage: Landowners and Politics in Punjab." $\begin{array}{llllll}\text { History } & \text { and } & \text { Anthropology } & 22 & \text { (3): } & 337-69 .\end{array}$ https://doi.org/10.1080/02757206.2011.595006.

Johnson, Paul D. 1994. Teori Sosiologi: Klasik dan Modern, Jilid I dan II, Terj. Robert M.Z. Lawang. Gramedia: Jakarta.

Keith, Legg. 1983. Patron Client and Politicism Institute of International Studies. Berkeley: University of California.

Koentjaraningrat. 1972. Beberapa Pokok Antropologi Sosial. Jakarta: Dian Rakyat.

Komter, Aaefke. 2005. Social Solidarity and The Gift. New York: Cambridge University Press. Leonard, David K., Jennifer N. Brass, Michael Nelson, Sophal Ear, Dan Fahey, Tasha Fairfield, Martha Johnson Gning, et al. 2010. "Does Patronage Still Drive Politics for the Rural Poor in the Developing World? A Comparative Perspective from the Livestock Sector." Development and Change 41 (3): 475-94. https://doi.org/10.1111/j.14677660.2010.01647.x.

Maus, Marcell. 1994. The Gift, Form and Function Echange in Archaic Societies, Terjem. Jakarta: Yayasan Obor Indonesia.

Mccauley, John F. 2013. "Africa's New Big Man Rule? Pentecostalism and Patronage in Ghana." African Affairs 112 (446): 1-21. https://doi.org/10.1093/afraf/ads072.

Mirajiani, Ekawati S.Wahyuni, Arif Satria, Saharuddin, Tridoyo Kusumastantol. 2014. "Transformasi Pranata Patronase Masyarakat Nelayan: dari Ekonomi Moralitas Menuju Ekonomi Pasar". Jurnal Komunitas; Reasearch\&Learning in Sociology and Anthropology. 6 (1): 115-134.

Morgan, Stephen L., Ismaila Z. Mohammed, and Salisu Abdullahi. 2010. "Patron-Client 
Relationships and Low Education among Youth in Kano, Nigeria." African Studies Review 53 (1): 79-103. https://doi.org/10.1353/arw.0.0236.

Parkin, Robert\&Linda Stone, (Eds.). 2004. Kinship and Family; An Anthropological Reader. USA: Blachwell Publishing.

Polo Y La Borda, Adolfo. 2019. "Don Mauro's Letters: The Marquis of Villagarcía and the Imperial Networks of Patronage in Spain." Americas 76 (4): 555-83. https://doi.org/10.1017/tam.2019.70.

Popkin, Samuel L. 1979. The Rational Peasant; The Political Economy of Rural Society in Vietnam. Illinois, F Peacock Publisher Inc..

Purwaningsih, Titin. 2015. "Politik Kekerabatan dan Kualitas Kandidat di Sulawesi Selatan". Jurnal Politik. 1 (1), Agustus: 97-123.

Schneider, William M\&Mary Jo Schneider, 2004. "Selako Male Initiation". Jurnal Ethnology, 30 (3).

Scott, James C. 1972. "Patron-Client Politics and Political Change in Southeast Asia". Dalam Jurnal American Political Science Review. 66 (1): 91-113.

Setiawan, Eko. 2012. "Eksistensi Budaya Patron Klien dalam Pesantren: Studi Hubungan antara Kiai dan Santri”. Jurnal Ulul Albab, Volume 13, Nomor 2. DOI: http://dx.doi.org/10.18860/ua.v0i0.2372: 137-152.

Shahab, Yasmin Zaki. 2005. "Sistim Kekerabatan sebagai Katalisator Peran UlamaKeturunan Arab di Jakarta". Jurnal Antropologi Indonesia. 29 (2): 123-141.

Smith, Daniel Jordan. 2004. "Burials and Belonging in Nigeria: Rural-Urban Relations and Social Inequality in a Contemporary African Ritual". Jurnal American Anthropologist. New Series. 106 (3): 569-579.

Supartiningsih. 2010. "Konsep Ajjoareng-Joa' dalam Tatanan Sosial Masyarakat Bugis (Perspektif Filsafat Sosial)", Jurnal Filsafat. 20 (3), Desember: 217-238.

Suprihatin, Sri Emy Yuli. 2002. "Hubungan Patron Klien Pedagang Nasi Kucing di Kota Yogyakarta". Jurnal Penelitian Humaniora. 7 (I), April: 147-16.

Turmudi, Endang. 2003. Perselingkuhan Kiyai dan Politik. Jakarta: LP3ES.

Viere, Grace M. 2001. "Examining Family Ritual”. The Family Jounal. 9, Juli: 285-288.

Vokes, Richard. 2016. "Primaries, Patronage, and Political Personalities in South-Western Uganda." Journal of Eastern African Studies 10 (4): 660-76. https://doi.org/10.1080/17531055.2016.1278324.

Webster. 1975. Webster's New Twentieth Century Dictionary. Edisi Kedua (Oxford: Oxford University Press.

Zamroni, Imam. 2007. "Kekuasaan Juragan dan Kiai di Madura”, Jurnal Karsa. XII (2): 168179. 